\title{
ANALYZING ECONOMIC STRUCTURE AND COMPARING THE RESULTS OF THE PREDICTED ECONOMIC GROWTH BASED ON SOLOW, FUZZY-LOGIC AND NEURAL-FUZZY MODELS
}

\author{
Mirnaser Mirbagheri $^{1}$, Namiq Tagiev $^{2}$ \\ ${ }^{1}$ Islamic Azad University Ardebil Branch, Ardebil, Iran \\ ${ }^{2}$ Department of Mathematical Economics in Baku State University, Baku, Azerbaijan \\ E-mails: ${ }^{1}$ Mirbagheri_hir@yahoo.com (corresponding author); ${ }^{2}$ NTagiev@yahoo.com
}

Received 27 July 2009; accepted 5 January 2011

\begin{abstract}
Investigating the factors effective on economic growth is of great importance for most economists. Although lots of studies have been done on economic growth in the world, it has less been regarded in Iran. In this article, by estimating growth regression, we attempt to investigate the supply side of economic growth in Iran. Then we compare the predictive results of Fuzzy-logic, Neural-Fuzzy and Solow models. The results show that there was negative significant relationship (i.e. -0.035 ) between unstable policy and economic growth rate in Iran during investigation period (1959-2001). In this model, the effect of expenses used by government is positive (i.e. 0.01). Furthermore, the estimated results of long term relationship show that the variable coefficients of capital, labor power, exportation, and inflation are $0.319,0.016,0.001$, and -0.001 , respectively. And also by comparing the predictive results of models for the average percent of annual growth, it is predicted that the average percent of Solow, Neural-Fuzzy, and Fuzzy-logic models are 7.17\%, $5.92 \%$, and $6.46 \%$ for $2002-2006$, respectively. Evaluation of results from the models on the basis of criteria shows that model Neural-Fuzzy predicts better than Fuzzy-logic and Solow models. In other words, forecasting by the model Neural-Fuzzy is recommended.
\end{abstract}

Keywords: Solow model, forecasting the growth, Fuzzy-logic, Fuzzy Neural Network (FNN), economic structure, economical factors, economic growth, supply side of economics.

Reference to this paper should be made ad follows: Mirbagheri, M.; Tagiev, N. 2011. Analyzing economic structure and comparing the results of the predicted economic growth based on solow, Fuzzy-logic and Neural-Fuzzy models, Technological and Economic Development of Economy 17(1): 101-115.

JEL Clasification: C13, C15, C44, C45, C53.

\section{Introduction}

Economic growth is the most important index among the macroeconomic variables. This variable has been considered as an economical index of government, and its increasing rate 
shows the welfare condition of the society. Thus, applying suitable economical policies, and recognizing effective factors in economic growth, have always been more important for politicians and economists. Since forecasting economic growth seems to be one of the main parameters of decision makings for governmental and private-sector programmers, identifying effective factors on economic growth, linear and non-linear models (Solow) and (Fuzzy-logic and Neural-Fuzzy) have been designed to achieve more accurate predictions.

This article attempts at first to recognize the effective variables which effect economic growth in Iran (Mirnaser 2008), then it will apply appropriate means for modeling and forecasting the main macroeconomic variables such as economic growth. In order to obtain a desirable model, we also try to examine and analyze the main and important effective factors in economic growth. This estimation can be led to applying appropriate, suitable and effective decisions. For this estimation, we use Solow model, then on the basis of existing variables in this model, we design Fuzzy-logic and Neural-Fuzzy to compare the results. The data are based on the information gathered from informative centers such as Central Bank, Planning Budgeting Organization (P.B.O.) and Statistical Centers.

\section{Materials and methods}

For investigating the procedures of each economic system, we consider some indicators. One of these indexes is the actual gross domestic product (G.D.P) which shows the total economic activity of the country. By the actual gross domestic product index, we can determine the ratio of the process of progression, depression, and economic recession. In fact, this index shows the productive processes of goods and services.

Thus, in order to reach stable internal growth, it is better to remove factor such as inflation which has negative effect on production as well as investment (Nili 1997).

Historically the main factor in economic growth is investment, and for creating a balance between institutions and families, family savings should be equal to investments of institutions. Thus, there should be a relationship between investment and savings (Reblo 1998).

Although increase in physical capital leads to increase in economic growth, not all economical instability can be explained by saving physical capital (Quah 2002). Thus, in order to determine the role of production instability, technology has been used as an independent variable in growth models, and Solow is considered as one of the pioneers (Keely and Quah 2000). The economical expense of government is the second means that considerably effects on economic growth. In investigating this political means, at first, we should pay attention to preparing the financial part of expenses of government by tax collecting or by attracting the natural resources of government (Shafiei 2006; Tanzi 1986).

Ram (1986) states that the effect of government on economic growth is always positive and the external effects of government have partly been positive effects, because most of government expenses have been used for education, health, hygiene, etc. In this article, the consuming expenses have been called human being capital.

Human being capital can not compensate for decrease in physical capital. Thus, decrease in physical capital leads to decrease in economic growth. Furthermore, whether human be- 
ing capital can compensate for the physical capital or not, depends greatly on technology (Tanzi 1986).

On the basis of previous experiences and theories, we may divide the effective variables of economic growth in Iran into 8 parts: 1) investment and physical capital, 2) labor power, 3) human capital, 4) business, 5) credit and money variables, 6) inflation, 7) government, 8) political situation. In order to study the effect of mentioned factors on economic growth, it is better to choose, and test a variable which matches with the economic structure of Iran (Mirnaser 2008; Mirnaser and Tagiev 2009).

The literature of prediction has been done by researchers such as: Zhang et al. (1998) and recent applications have also been done by Swanson \& White (1997a), and Darbellay and Slama (2000), and Qi (2001), and Tkacz (2001), but despite the power and reputation of these models, the function of neural network models in predictive experiment is combinatory (Zhang et al. 1998). In the field of economic data, Swanson and White (1997b), studied performance of neural network models in predicting macroeconomic time series. In the U.S., focusing on integration of production in industry, Moody et al. (1993) understood that the neural network model, in the horizon of 6 months and more, is preferred to the linear model.

Tkacz (2001) showed that during a year, production of Gross domestic of Canada by neural network, was predicted better than linear models. In other different applications Qi (2001) showed that the neural network models were helpful in predicting binary variable of economic crisis.

In terms of combination, fuzzy-logic of fuzzy neural networks lots of researches have been done. Kuo et al. (2001) have offered ANN as an appropriate fuzzy inference system by a fuzzy modeling “Takagi-Sugeno”.

Buckley and Hayashi (1994) have analyzed new findings in the learning algorithm and its applications for FNN. FNN emphasized in the above, is suitable only for numerical data. But knowledge of experts is usually fuzzy type. Therefore, researchers have done some efforts to solve this problem. Ishibuchi et al. (1995) have also offered other learning methods for neural networks. This methods are used not only for numerical data, but also are often used by experts for "if - then", fuzzy rules. Le Cun (1985) and Lee (1990) have presented an FNN, which is able to control the input and output of the Fuzzy. Kuo et al. (1998) also offered an intelligent decision support system based on fuzzy neural networks for prediction.

\subsection{Solow model}

In this part, we will show the Solow model which has been used by economists to study growth and this is the starting point for analyzing growth. This model consists of four variables: $(\mathrm{A}, \mathrm{L}$ or N, K, and Y) (Romer 1958), and productivity is used to measure the degree of production factors (Branson 1979).

By using the final production, the capability of one factor in production can be determined. In order to estimate economic growth, we use neoclassical model of economic growth introduced by Solow. Thus production function can be shown as:

$$
Y_{t}=A(t) . F\left(K_{t}, N_{t}\right) .
$$


$\mathrm{Y}_{\mathrm{t}}$ stands for production in time, $\mathrm{K}_{\mathrm{t}}$ stands for capital and $\mathrm{N}_{\mathrm{t}}$ stands for labour power (Yavari and Nader 2001). In this model A(t) shows developing index which can be shown as:

$$
\mathrm{A}(\mathrm{t})=A \cdot \mathrm{e}^{\lambda \cdot \mathrm{t}}
$$

For diferenciating production function of Solow from economic growth, we differentiated it from the mentioned production function. By differentiating production function, we can determine the ratio of production function to capital variation and labour power. The total differential of the production function is shown as:

$$
d y_{t}=f\left(k_{t}, N_{t}\right) d A_{(t)}+A \frac{\partial \mathrm{f}}{\partial \mathrm{K}} \cdot d k+A \cdot \frac{\partial f}{\partial N} \cdot d N .
$$

If we divide them by $y_{t-1}$, we will have:

$$
\frac{d y_{t}}{y_{t-1}}=f\left(K_{t}, N_{t}\right) \frac{d A_{(t)}}{y_{t-1}}+A \frac{\partial \mathrm{f}}{\partial \mathrm{K}} \cdot \frac{d k}{y_{t-1}}+A \cdot \frac{\partial f}{\partial N_{t-1}} \cdot \frac{d N_{t}}{y_{t-1}} .
$$

By using the first formula, the forth formula can be written as:

$$
\frac{d y_{t}}{y_{t-1}}=\frac{d A_{(t)}}{A_{(t)}}+A \cdot \frac{\partial \mathrm{f}}{\partial \mathrm{K}_{t}} \cdot \frac{d k_{t}}{y_{t-1}}+A \cdot \frac{\partial f}{\partial N_{t}} \cdot \frac{d N_{t}}{y_{t-1}} .
$$

Because of continuity in the economical equation in fifth formula, it can be written as:

$$
\frac{\Delta y_{t}}{y_{t-1}}=a_{0}+a_{1} \frac{\Delta k_{(t)}}{y_{t-1}}+a_{2} \frac{\Delta N_{t}}{y_{t-1}}
$$

In this formula $a_{1}=A_{1} \frac{\partial f}{\partial k_{1}}$ shows the final capital productivity and $a_{2}=A \frac{\partial f}{\partial N_{t}}$ shows the final labour power productivity. Because of dualistic economy such as oil duality, the Solow model isn't more effective. By analysing the existing economical situation of Iran , we adapt the mentioned model with the economic structure of Iran (Mirnaser and Tagiev 2009).

By investigating and analyzing economic structure of Solow production function which was mentioned in formula (1), we change it according to the economic conditions of Iran as follows:

$$
y_{t}=A(t) \cdot f(k, L(\text { or }) N, c g, x, p(\text { or }) c p i, D) .
$$

In this formula, $y_{t}$ or $G D P_{t}$ stands for gross domestic product, $K$ stands for capital, $L$ or $N$ stand for labor power, CG stands for the consuming expenses of government (human being capital), $X$ stands for exportation, P or CPI stands for inflation, and DUM stands for dummy variables.

After differentiating, the mentioned formula appears as:

$$
\begin{aligned}
& \frac{\Delta y_{t}}{y_{t-1}}=\frac{\Delta A_{(t)}}{A_{(t)}}+A(t) \cdot \frac{\partial \mathrm{f}}{\partial N} \cdot \frac{\Delta N_{t}}{y_{t-1}}+A(t) \cdot \frac{\partial f f}{\partial k} \cdot \frac{\Delta k}{y_{t-1}}+A(t) \frac{\partial}{\partial x} \cdot \frac{\Delta x}{y_{t-1}}+ \\
& A(t) \cdot \frac{\partial f}{\partial(c p i)} \cdot \frac{\Delta(c p i)}{y_{t-1}}+A(t) \cdot \frac{\partial f}{\partial D} \cdot \frac{\Delta D}{y_{t-1}} .
\end{aligned}
$$


This formula also can be written as:

$$
G G D P=a_{0}+a_{1} D k g d p+a_{2} D L g d p+a_{3} D c g g d p+a_{4} R x+a_{5} c p i+a_{6} D U M
$$

According to the statistical data for 1959-2001, the above formula has been explained as:

- GGDP: Non-oil-gross domestic product growth,

- DLGDP: The ratio of labor power variation to GDP,

- DKGDP: The ratio of stock capital variation to GDP,

- DCGGDP: The ratio of changing consuming expenses of government to GDP (human being capital),

- RX: Non-oil exportation growth,

- CP1: The rate of inflation,

- DUM: The dummy variable which stands for political instability.

\subsection{Fuzzy-Logic Model}

Fuzzy-logic provides a practicable way to understand and manually influence the mapping behavior. In general, fuzzy logic uses simple rules to describe the system of interest rather than analytical equations and makes it easy to implement. It is obvious that forecasting activities play an important role in our daily life. We usually forecast many things concerned with our daily lives, such as economy, stock market, population growth, weather, etc. Forecasting with $100 \%$ accuracy may be impossible, but we can do our best to reduce forecasting errors. To solve forecasting problems, many researchers have proposed many different methods or models (Cheng 2004). Fuzzy systems have supplanted conventional technologies in some scientific applications and engineering systems in the past decade (Cheng 2004).

Fuzzy logic has the ability to express the ambiguity of human thinking and translate expert knowledge into computable numerical data. A fuzzy system consists of a set of fuzzy if-then rules. Conventionally, the selection of fuzzy if-then rules often relies on a substantial amount of heuristic observation to express the knowledge of proper strategies. Obviously, it is difficult for human experts to examine all the input-output data from a complex system to find proper rules for the fuzzy system. To cope with this difficulty, several approaches have been proposed to generate fuzzy if-then rules from numerical data (Cheng 2004). An Fuzzy Inference Systems (FIS) contains three main components of fuzzification stage, the rule base and the defuzzification stage. The fuzzification stage is used to transform the so-called crisp values of the input variables into fuzzy membership values. Then, these membership values are processed within the rule-base, using conditional 'if-then' statements. The outputs of the rules are summed and defuzzified into a crisp analogue output value. The effects of variations in the parameters of an FIS can readily be understood and this facilitates calibration of the model. 
Fuzzy-logic implemented system, includes six inputs and one output which have been implemented on the basis of principles or rules of triangular with mathematical formulas which are:

$$
\mu_{3}(x, a, c, b)=\left\{\begin{array}{cl}
0, & \text { if } x \leq a ; \\
\frac{x-a}{c-a}, & \text { if } a<x<c ; \\
\frac{b-x}{b-c}, & \text { if } c<x<b ; \\
0, & \text { if } x \geq b .
\end{array}\right.
$$

Real numbers of variables are converted to fuzzy values. And then these fuzzy values are inserted in the basic process ("if-then" rules) and then, they are based on linguistic value levels: low, middle, high, very high and are graded by membership functions. And then the output values (results) of rules, with no-fuzzy building (defuzzification) of type gravity center, are converted to the real numbers.

\subsection{Neural-Fuzzy Model}

Artificial neural networks (ANN) appear to be particularly suitable to forecast the growth of time series, as they can learn highly nonlinear models, hold effective learning algorithms, handle noisy data, and use inputs of different kinds (Armano et al. 2005). ANNs have been designed to mimic the characteristics of the biological neurons in the human brain and nervous system (Zurada 1992). An ANN creates a model of neurons and the connections between them, and trains it to associate output neurons with input neurons. The network "learns" by adjusting the interconnections (called weights) between layers. When the network is adequately trained, it is able to generate relevant output for a set of input data. One of the valuable properties of neural networks is that of generalization where, by a trained neural network, it will be able to provide a correct matching in the form of output data for a set of previously unseen input data. Back Propagation (BP) is one of the most famous training algorithms for multilayer perceptions (Abraham and Nath 2001; Kasabov 1998).

Basically, BP is a gradient descent technique to minimize the error for a particular training pattern. FNNs are a class of hybrid intelligent algorithms that integrate fuzzy-logic with ANNs. A fuzzy neural network system is defined as a combination of ANN and fuzzy inference system (FIS) in such a way that neural network learning algorithms are used to determine the parameters of FIS. An even more important aspect is that the system should always be interpretable in terms of fuzzy if-then rules, because it is based on the fuzzy system reflecting vague knowledge (Sadeghi et al. 2008). A neural network - Fuzzy consists of five levels, which are as follows (Abraham and Nath 2001):

1 - Input Layer,

2 - Fuzzification Layer,

3 - RuleBase Layer,

4 - Fuzzy Outputs,

5 - Output Layer. 
In designing neural networks - Fuzzy model, Multi-layered Feed forward Neural Network (MFNN) with learning algorithm, the propagation error and fuzzy inference system "Sugeno" input function "difference between Sigmoid functions" and the output linear function has been used in this system. On the other hand, moving average function has also been used for non-fuzzy In order to design the optimum system, neural network - Fuzzy were evaluated through continuing changes in number of layers and number of hidden neuron layers, and appropriate neural network topology. Through continuous changes in membership functions, and number of membership functions, the suitable fuzzy inference system was designed.

\subsection{Explanation of fuzzy neural networks}

Takagi-Sugeno-Kang fuzzy inference system is used to design the FNN for growth forecasting. The current model has 3 built-in membership functions composed of the difference between two sigmoid membership functions for each input variables with the evolving parameters:

1. Number of training epochs $=10$,

2. Training error goal $=0$,

3. Step-size for each epoch $=1$,

4. Learning rates for first and second layer $=0.05$.

FNN uses a single pass training approach. And the network parameters were determined using a trial and error approach. The training was repeated 10 times after reinitializing the network and the worst errors were reported (The error and Structure of FNN are shown in Figs 1 and 2).Some performing criteria are usually used to show how to learn data connection in neural network - fuzzy set. For Prediction, these criteria are often related to the error between the predicted outputs and the real desired outputs.

- The Square mean of standard error = MSE,

- The square root mean of square error $=$ RMSE,

- The normalized mean square of standard error = NMSE,

- Coefficient of determination and its value is between zero and one $=\mathrm{R} 2$,

- And the value of one indicates complete adaptation. R2 = 1-NMSE,

- The mean of absolute error $=$ MAE,

- The average percent of absolute error $=$ MAPE.

\section{Discussion}

In this study, for determining the regression growth of Iran, we use the changing ratio of variable to GDP. Results from the augmented Dickey-Fuller unit Root test show that all of under consideration variables enjoy validity. In other words, they are stationary. This study attempts to compare the forecasted power of non-linear models (Fuzzy-Logic and Neural-Fuzzy) with the linear model (Solow). For this purpose, we use 5 to 10 percent of sample data for evaluating the forecasting power of model. In this research two periods of 2002-2006 have been considered and control data has been selected. According to different regressions and introduced variables in 1959-2001, the best models have been chosen as follows (the common criteria was based on $R^{2}$, the ratio of $\mathrm{F}$ and the significant relationship of coefficient): 


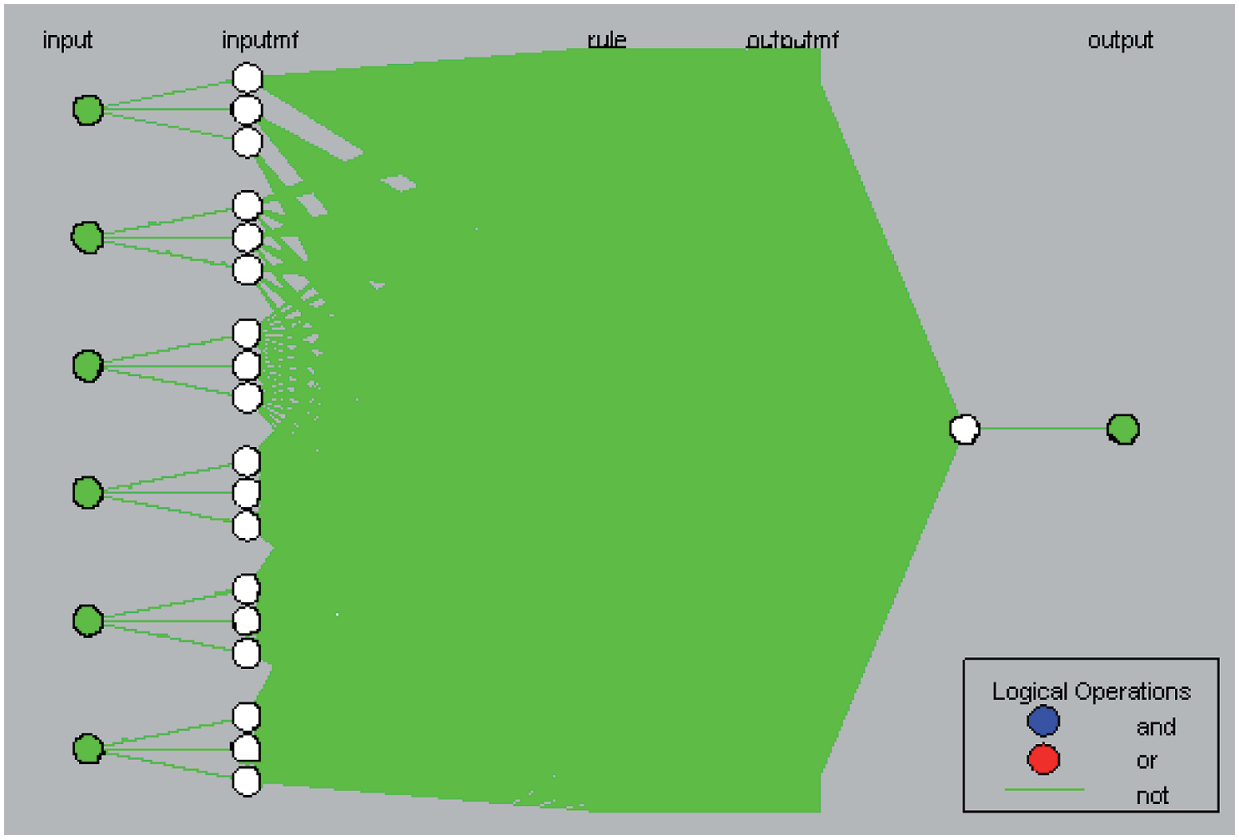

Fig. 1. The Structure of FNN

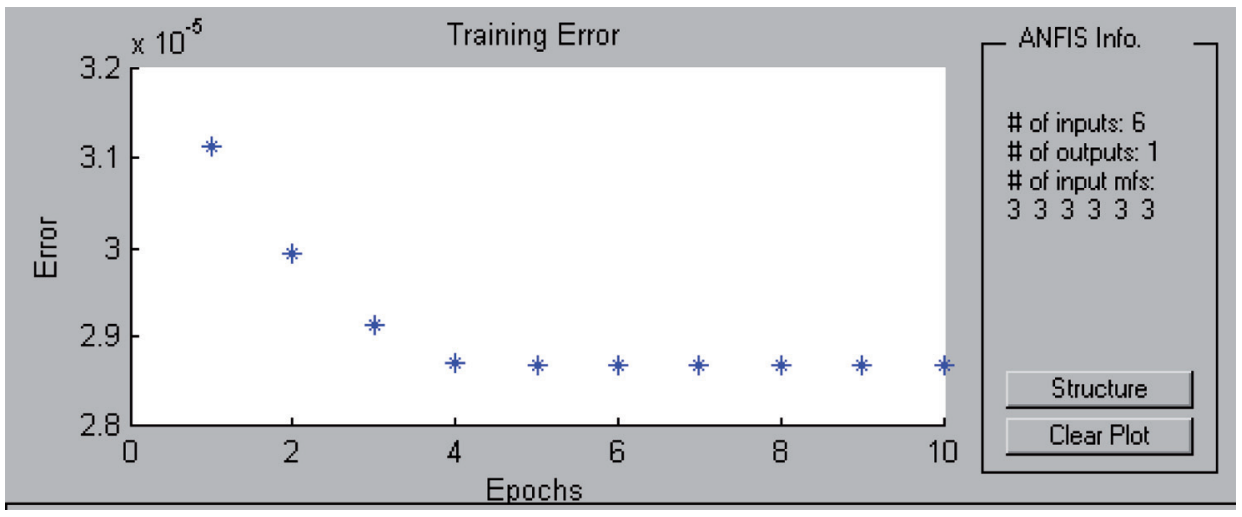

Fig. 2. RMSE reduction of GDP growth by using FNN with the normalized data

GGDP $=0.042+0.016$ DLGDP + 0.319 DKGDP + 0.010 DCGGDP + 0.001 RX - 0.001CPI- 0.035 DUM.

$$
\begin{aligned}
& \mathrm{t}=(2.59) \quad(2.24)(3.21) \quad(2.08)(5.32) \quad(-2.45) \quad(-2.56) \\
& R^{2}=0.84 \quad R_{a}^{2}=0.82 \quad \mathrm{DW}=1.65 \quad \mathrm{~F}=32.53 \\
& \mathrm{~F} \text { (White Heteroscedasticity test })=1.14 \\
& \mathrm{~F}(\mathrm{LM} \text { Test })=0.54
\end{aligned}
$$


The credibility of model: as you see (in Figs 3 and 4), there is certain expected coefficient. GGDPF:

G; growth,

GDP; gross domestic of product,

F; forecasting.

$R^{2}$ shows that 84 percent of economic growth variable changes have been explained by independent variables. This criterion which is a static model has been considered as a good coefficient. D.W and LM tests show that there isn't any significant autocorrelation between

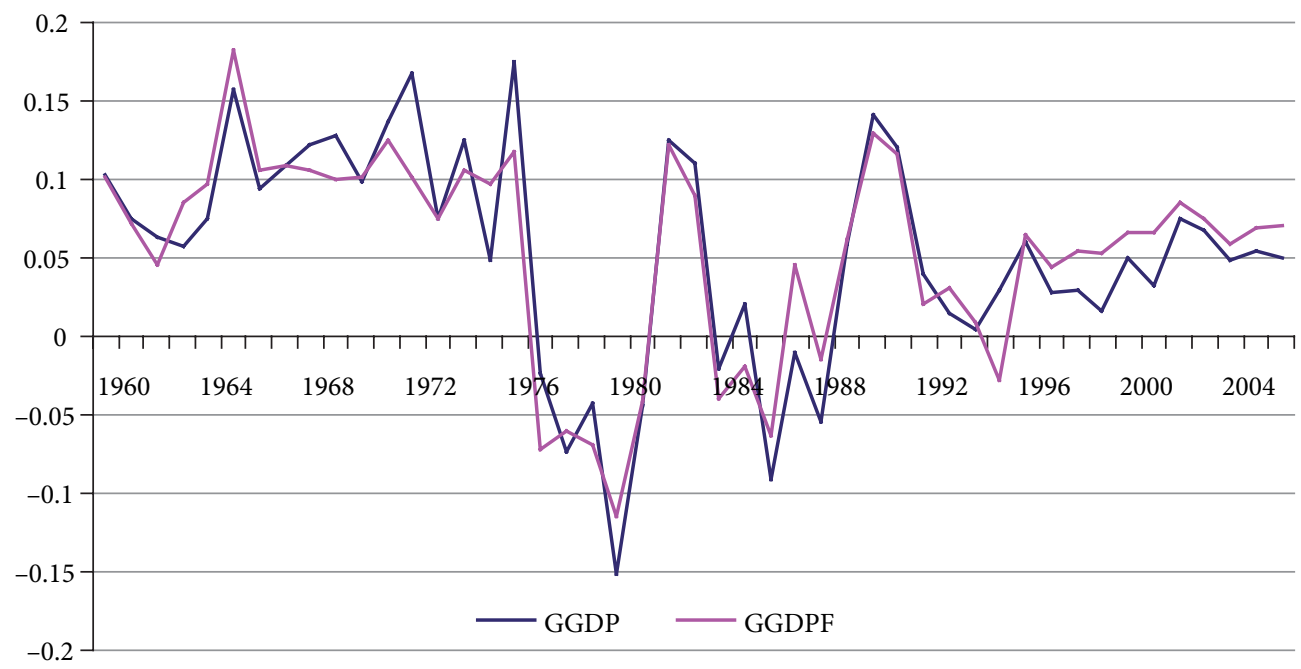

Fig. 3. Comparison of predicted economic growth on the basis of Solow model (GGDPF) with actual GGDP

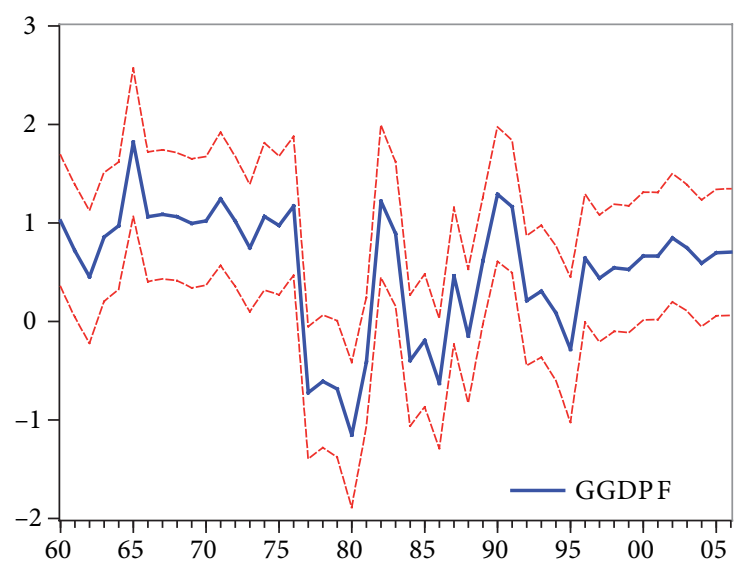

\begin{tabular}{|c|c|}
\hline \multicolumn{2}{|c|}{$\begin{array}{l}\text { Forecast: GGDPF } \\
\text { Actual: GGDP } \\
\text { Forecast sample: } 1959-2006 \\
\text { Adjusted sample: } 1960-2006 \\
\text { Included observations: } 47\end{array}$} \\
\hline \\
\hline \multicolumn{2}{|l|}{$\begin{array}{l}\text { Root Mean Squared Error } \\
\text { Mean Absolute Error }\end{array}$} \\
\hline Mean Abs. Percent Error & 58.59469 \\
\hline \multicolumn{2}{|l|}{ Theil Inequality Coefficient } \\
\hline Bias Proportion & 0.002346 \\
\hline Variance Proportion & 0.036954 \\
\hline Covariance Proportion & 0.960700 \\
\hline
\end{tabular}

Fig. 4. The predicted economic growth on the basis Solow model (GGDPF) 
descriptive variables. In other words, LM- Breusch Gadferi test disproves the autocorrelation between them.

F Statistic shows that regression itself is very credible and according to White Heteroscedasticity test there is Homoscedasticity between disturbing elements. The important point which has been concluded in this research is that there is negative significant relationship between DUM (instability) and economic growth in mentioned periods. The long term relationship shows that the stock capital variable coefficient is equal to 0.319 , i.e. one billion Riyals increase in capital causes gross national product to be increased by 0.319 . Here, the coefficient of labor power is 0.016 .

The results show that, in Iran, the effect of physical capital on economic is greater than that of labor power. In other words, for producing a unique production in macroeconomic, capital has more effect on production than labor power. In this model, the effect of human being capital (consuming expenses of government) is 0.01 . Although educational and health expenses are considered as two parts of common expenses of government and the main parts of human being capital, they are also considered as productive expenses. However, the results show the positive effect of human being capital (common expenses of government) on economic growth and production. The purpose of this study is to estimate economic growth, and to provide a suitable model for predicting growth in the future. Therefore, this study focuses on developing accurate methods for exact and reliable prediction. For this purpose, the spectrum of linear and nonlinear methods, have been investigated. And Solow method is used as the linear method and the methods of Fuzzy-logic and Neural-Fuzzy are also used as non-linear methods, in prediction and it has been compared on the basis of six criteria: R2, MAPE, MAE, NMSE, RMSE, and MSE.

Since each of the above mentioned criteria evaluates special aspects, all of them have been used. Results from performing evaluation of criteria which have been mentioned in Table 1 used different methods for testing data. As seen in Table 1 in term of all performance, Fuzzy neural network method is better than the Fuzzy-logic method, and Solow. Comparison of predicted results on the basis of Solow, Fuzzy logic and Neural-Fuzzy, with real values have been shown in Table 2 and Fig. 5. The predicted values with fuzzy neural networks are approximately consistent with real values. Considering that, Fuzzy neural networks compared with two other methods in performance evaluation of six criteria are superior; this method is recommended for predicting economic growth. The Predicted values have been shown in Table 2.

Table 1. Forecasting results of FNN, F-Logic, and Solow

\begin{tabular}{lcccccc}
\hline & RMSE & MSE & NMSE & MAPE & MAE & $\mathbf{R}^{2}$ \\
\hline FNN & $4.5158 \mathrm{e}-005$ & $2.0393 \mathrm{e}-009$ & $1.5947 \mathrm{e}-006$ & $2.4940 \mathrm{e}-004$ & $1.0013 \mathrm{e}-005$ & 1.00 \\
\hline F-Logic & 0.0081 & $6.4808 \mathrm{e}-005$ & 0.1032 & 0.0779 & 0.0042 & 0.8968 \\
\hline Solow & 0.0137 & $1.8676 \mathrm{e} 004$ & 0.1460 & 0.1615 & 0.0040 & 0.8540 \\
\hline
\end{tabular}


Table 2. Comparison of prediction models: FNN, Solow, and F-Logic With real values

\begin{tabular}{ccccc}
\hline Years & Real & Solow & F-Logic & FNN \\
\hline 2002 & 0.0756 & 0.0848 & 0.0778 & 0.0755 \\
\hline 2003 & 0.0683 & 0.0747 & 0.0785 & 0.0682 \\
\hline 2004 & 0.0484 & 0.0591 & 0.0495 & 0.0484 \\
\hline 2005 & 0.0539 & 0.0698 & 0.05 & 0.0538 \\
\hline 2006 & 0.05 & 0.0703 & 0.0675 & 0.0503 \\
\hline average & 0.05924 & 0.07174 & 0.06466 & 0.05924 \\
\hline percent & $5.924 \%$ & $7.174 \%$ & $6.466 \%$ & $5.924 \%$ \\
\hline
\end{tabular}

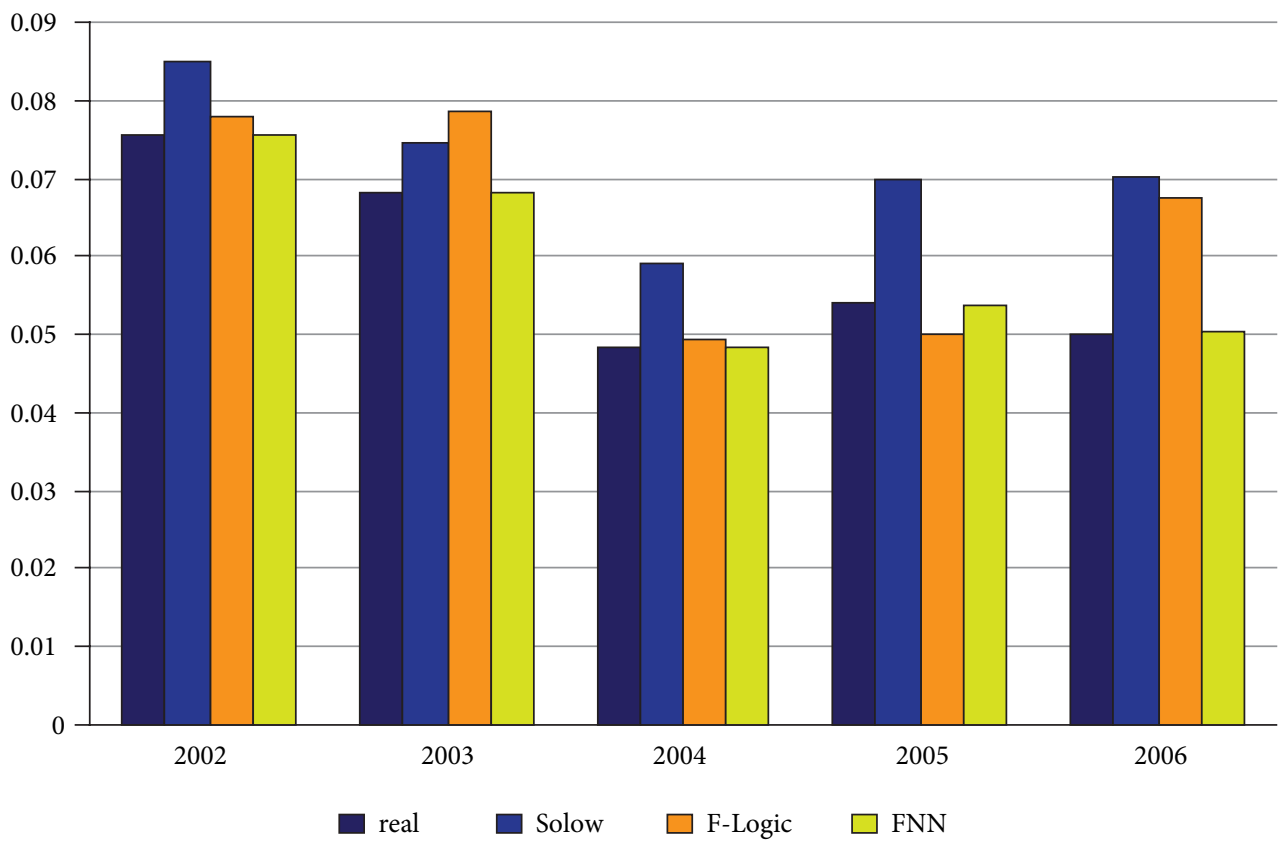

Fig. 5. Comparison of prediction models: FNN, Solow, and F-Logic with real values

\section{Conclusions}

Studying different aspects of economic growth of Iran can be important for two reasons. Firstly, it is important for politicians to make appropriate governmental decisions, secondly, for economists to get appropriate economic planning for the country as well as the economical institutions.

Research results indicate that in terms of all performing criteria, fuzzy neural networks are better than Fuzzy-logic method and Solow, and in terms of more performing criteria, the 
fuzzy logic method, is better than Solow method. For example, in terms of RMSE criterion (equal to 4.5158e-005) that has been shown in Table 1, error rate of fuzzy neural networks, is remarkably less than the Solow method (0.0137).

The main reason for this is that the predictive data of economic growth bear non-linear nature.

If the used data weren't non-linear, the error rates of fuzzy neural network method wouldn't be so much. And even the linear method Solow, offers the better answer.

The experimental results of this study and the similar researches have shown that Fuzzy neural networks have been successful and predictive errors have been remarkably decreased. And it has significant features in the rapid convergence, high precision and strong ability in the function approximation.

Because fuzzy neural network system doesn't need explicit, definite, and large sample data, it can be a great prediction of economic growth, and surely this method is better than predicted classical methods.

Finally, it should be mentioned that FNN model has given appropriate results in predicting economic growth.

For further research, investigators are referred to use it in different fields of sciences - such as studies about taxes, inflation, exchange rates, tourism, exports, imports, etc. - and compare it with other models and evaluate the accuracy of predicting by FNN model.

\section{Acknowledgement}

I wish to acknowledge my appreciation to Organization of Management and planning of Ardebil Province, Bank Markazi of Islamic Republic of Iran, and Statistics Center of Iran. I further wish to thank Mr. Dr Nader Mehregan, Mr. Dr Amir Afsar, Mistress. Dr Naila Valieva, Mistress. Dr Shafiga Mammadova and Mr. Engineer Ebrahim Abdi for giving invaluable suggestions and comments.

\section{References}

Abraham, A.; Nath, B. 2001. A neuro-fuzzy approach for modeling electricity demand in Victoria, Applied Soft Computing 1: 127-138. doi:10.1016/S1568-4946(01)00013-8

Armano, G.; Marchesi, M.; Murru, A. 2005. A hybrid genetic-neural architecture for stock indexes forecasting, Information Sciences 17: 3-33. doi:10.1016/j.ins.2003.03.023

Branson, H. W. 1979. Macroeconomic theory and policy. Translated by A. Shakeri. Tehran: Ney Press. 808 p.

Buckley, J. J.; Hayashi, Y. 1994. Fuzzy neural networks: a survey, Fuzzy Sets and Systems 66: 1-13. doi:10.1016/0165-0114(94)90297-6

Cheng, J. L. 2004. Time series prediction using adaptive neuro-Fuzzy Networks, International Journal of Systems Science 35(5): 273-286. doi:10.1080/00207720410001714130

Darbellay, G. A.; Slama, M. 2000. Forecasting the short-term demand for electricity: do neural networks stand a better chance, International Journal of Forecasting 16: 71-83.

doi:10.1016/S0169-2070(99)00045-X 
Ishibuchi, H.; Kwon, K.; Tanaka, H. 1995. A learning algorithm of fuzzy neural networks with triangular fuzzy weights, Fuzzy Sets and Systems 71: 277-293. doi:10.1016/0165-0114(94)00281-B

Kasabov, N. 1998. Evolving fuzzy neural networks: algorithms, applications and biological motivation, in T. Yamakawa; G. Matsumoto (Eds.). Methodologies for the Conception, Design and Application of Soft Computing, World Scientific, Singapore, 271-274.

Keely, L. C.; Quah, D. 2000. Technology in growth, in Ed. Thijs Ruyter Van Steveninck. Economic growth and its Determinations (Amsterdam: KLUWER) Chapter 3, P. 75-99.

Kuo, R. J.; Chen, C. H.; Hwang, Y. C. 2001. An intelligent stock trading decision support system through integration of genetic algorithm based fuzzy neural network and Artificial neural network, Fuzzy Sets and Systems 118(1): 21-45. doi:10.1016/S0165-0114(98)00399-6

Kuo, R. J.; Lee, L. C.; Lee, C. F. 1998. Intelligent stock decision support system through artificial neural networks and fuzzy Delphi, Comput. Intell. Finance 6: 24-34.

Qi, M. 2001. Predicting US recessions with leading indicators via neural network Models, International Journal of Forecasting 17(3): 383-401. doi:10.1016/S0169-2070(01)00092-9

Quah, D. 2002. Technology dissemination and economic growth: Some lessons for the new economy, in Technology and the New Economy 3: 95-156. Ed. Chong-En Bai and Chi-Wayuen. Cambridge: MIT press.

Le Cun, Y. 1985. Une procedure dapprentissage pour reseau a seuil assymetrique [A training procedure for a threshold Unbalanced Network], Cognitive 85: 599-604.

Lee, C. C. 1990. Fuzzy logic in control systems: fuzzy logic controller, IEEE Trans. Systems Man Cybernet, Part I, 20(2): 404-418.

Mirnaser, M. 2008. Analysis Factors influencing on the Economical development, Physic-Mathematical Sciences Series, BDU 4: 90-96.

Mirnaser, M.; Tagiev, N. 2009. Reviewing and Analyzing the Economic growth and Economic structure of Iran, Transactions of National Academy of Sciences of Azerbaijan series of Economic 1: 126-130.

Moody, J.; Levin, U.; Rehfuss, S. 1993. Predicting the US index of industrial production, Neural Network World 3: 791-794.

Nili, M. 1997. Economics of Iran. Tehran, planning and budgeting organization. Research institutions. $490 \mathrm{p}$.

Ram, R. 1986. Government size and economic growth: A new framework and some evidence, cross section and Time series data, American Economic Review 1(76): 191-203.

Reblo, S. 1998. The role of knowledge and capital in economic growth. WIDER, Nation University. Working papers. 149.

Romer, D. 1958. The developed macroeconomic. Translated by M. Tagavi. Tehran, Islamic Azad University, Research and Scientific branch 1: 4-6.

Sadeghi, M. R.; Afsar, A.; Sohrabi, B. 2008. Inventory Lot-sizing with supplier Selection using hybrid intelligent algorithm, Science Direct, Applied Soft Computing 8: 23-29.

Swanson, N. R.; White, H. 1997a. A model selection approach to real time Macroeconomic forecasting using linear models and artificial neural networks, Review of Economics and Statistics 39: 540-550. doi:10.1162/003465397557123

Swanson, N. R.; White, H. 1997b. Forecasting economic time series using adaptive versus non adaptive and linear versus nonlinear econometric models, International Journal of Forecasting 13: 439-461. doi:10.1016/S0169-2070(97)00030-7

Shafiei, A. 2006. Examining the effect of financial policy on economic growth, Economical Research Journal 23: 81-112. 
Tanzi, V. 1986. Fiscal Policy Responses to Exogenous Shocks in Developing Countries, American Economic Review 76: 88-91.

Tkacz, G. 2001. Neural network forecasting of Canadian GDP growth, International Journal of Forecasting 17: 57-69. doi:10.1016/S0169-2070(00)00063-7

Yavari, K.; Nader, M. 2001. Using of abroad produced capitals and their usage in the economy of Iran, Nameye Mofid publication 27: 99-113.

Zhang, G.; Patuwo, B. E.; Hu, M. Y. 1998. Forecasting with artificial neural networks: the state of the art, International Journal of Forecasting 14: 35-62. doi:10.1016/S0169-2070(97)00044-7

Zurada, J. M. 1992. Introduction to Artificial Neural Systems. PWS Pub Company. 785 p.

\section{EKONOMINĖS STRUKTŪROS ANALIZĖ IR PROGNOZUOJAMO EKONOMINIO AUGIMO REZULTATŲ LYGINIMAS REMIANTIS SOLOVO, NEAPIBRĖŽTŲ AIBIŲ LOGINIU IR NEAPIBRĖŽTŲ AIBIŲ NEURONINIU MODELIAIS}

\section{Mirbagheri, N. Tagiev}

Santrauka. Ekonomikos augimo veiksnių tyrimas yra labai svarbus daugeliui ekonomistų. Nors visame pasaulyje buvo atlikta daug ekonomikos augimo tyrimų, tačiau tik keli jų susiję su Iranu. Šiame straipsnyje, nagrinejjant augimo tendencijas, stengiamasi ištirti Irano ekonomikos augimo priežastis. Prognostiniai duomenys buvo lyginami neapibrèžtų aibių loginiu, neapibrèžtų aibių neuroniniu ir Solovo modeliais. Rezultatai rodo reikšmingą neigiamą ryši (t. y. -0,035) tarp nestabilios politikos ir ekonomikos augimo tempų Irane tiriamuoju laikotarpiu (1959-2001 m.). Pagal ši modelị Vyriausybès išlaidų poveikis yra teigiamas (t. y. 0,01). Be to, skaičiavimai rodo, kad kintami kapitalo, darbo jegos, eksporto ir infliacijos koeficientai yra atitinkamai lygūs 0,$319 ; 0,016 ; 0,001$ ir -0,001. Lyginant 2002-2006 m. vidutinio metinio procentinio augimo prognozuojamus rezultatus gauta, kad jis Solovo, neapibrèžtų aibių loginiu ir neapibrèžtų aibių neuroniniu modeliais yra atitinkamai lygūs 7,17 \%, $5,92 \%$ ir 6,46 \%. Modelių testavimas rodo, kad neapibrěžtų aibių neuroniniu modelis prognozuoja geriau už neapibrež̌tų aibių loginị ir Solovo modelius. Kitaip tariant, rekomenduojamas neapibrèžtų aibių neuroniniu modelis.

Reikšminiai žodžiai: Solovo modelis, augimo prognozavimas, neapibrěžtų aibių loginis metodas, neapibrèžtų aibių neuroninis tinklas (NANT), ekonominè struktūra, ekonominiai veiksniai, ekonomikos augimas.

Mirnaser MIRBAGHERI. Having management record for six years as the head of economical affairs studies group and the head of Employment and Investment Group in Planning and Management Organization (previous Program and Budget Organization) of Ardebil Province. Getting Batchelor Degree in Mathematics from Islamic Azad University, Ardebil Branch in 1999, Master of Science Degree in Economical Sciences from Islamic Azad University, Tabriz Branch in 2003, and being busy as a PhD student in Economic and Mathematics in Comparative Mathematics Faculty of Baku State University (2010). A part-time faculty member of Economic Faculty of Payam-e-Noor University, Ardebil Branch; A part-time faculty member of Economic Faculty of Islamic Azad University, Ardebil Branch. Being engaged as an administrator or participating in, at least, five research plans, and also having at least 20 scientific articles.

Namiq TAGIEV has been graduated from Oil State University, Azerbaijan in oil and chemistry faculty in bachelor's degree and Master's degree in 1977-1982. In 1986 has been graduated from electronic faculty, Moscow, in PhD. In 1986-1996 has been busy teaching as associate professor and assistant professor in 
oil state university, and in 1996-2006 has been in charge of different posts in governmental organizations and economical systems of the country. Beginning from 2006, he has been the manager of Ministry of economical growth scientific researches of Azerbaijan for two years. Also, since 2006 he is the group manager of economic-mathematics in comparative mathematics faculty of state university of Baku, and has accomplished at least 100 scientific and research papers in fields of economy, econometrics, and investment. Research interests: accomplishing applied and operational plans; comparing the economical theories using mathematical methods; managing and organizing the research plans, Applied developing of mathematics. Applied development of mathematics economic sciences and technology. 